\title{
Attracting FDI to the Western Balkans: Special Economic Zones and Smart Specialisation Strategies
}

\author{
Will Bartlett \\ London School of Economics and Political Science, UK \\ W.J.Bartlett@lse.ac.uk

\section{Besnik Krasniqi} \\ University of Prishtina, Kosovo \\ besnik.krasniqi@uni-pr.edu

\section{Jasmina Ahmetbašić} \\ Sarajevo School of Science and Technology, Bosnia and \\ Herzegovina \\ jasminaahmetbasic@gmail.com
}

CroEconSur

Vol. 21

No. 2

December 2019

pp. 5-35

Received: November 19, 2018 Accepted: July 2, 2019

Research Article

doi:10.15179/ces.21.2.1

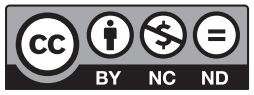

\section{Abstract}

This paper investigates the role of Special Economic Zones (SEZs) in the Western Balkans in supporting industrial policy for economic development. It shows that Serbia and North Macedonia have both implemented policies to establish networks of SEZs that have attracted a relatively large amount of new foreign direct investment, mainly into the motorcar and components industries. Although many jobs have been created and some improvements in export competitiveness have occurred, there is no evidence of improvements in labour productivity or widespread technology spill-over to local economies. The import intensity of production is extremely high, implying little linkage to local economies. The qualitative interviews further reveal limited linkages between SEZ-based companies and local businesses, limited technology transfer, and a 
lack of appropriate skills among the workforce. In particular, there is insufficient capacity in the motorcar components supply chain. The paper concludes that governments have used SEZ policies as an alternative to regional and local development policies based on smart specialisation. In order to take advantage of the opportunity offered by SEZs, governments in the region should put more effort into developing local supply chains, aligning their policies towards SEZs and smart specialisation in order to leverage the advantages of an increased inflow of direct foreign investment for sustainable economic development in the future.

Keywords: special economic zones, smart specialisation, technology transfer, skills, supply chains

JEL classification: L52, O25, O38, O52, O57

\section{Introduction ${ }^{1}$}

The Western Balkan region is an attractive location for foreign direct investment (FDI) due to its prospective EU membership, macroeconomic stability, strategic location, favourable taxes, diverse economies, low labour costs and relatively educated population (Sanfey, Milatović, \& Krešić, 2016). Despite these advantages, the inflow of FDI has historically been less than could be expected given its level of development and geographic closeness to EU markets (Estrin $\&$ Uvalić, 2014). Even though investor protection and investment promotion laws have improved over time, businesses still face high transaction costs in paying taxes, resolving insolvency, starting a business and enforcing contracts (Murgasova, Ilahi, Miniane, Scott, \& Vladkova-Hollar, 2015). In response to this situation, some countries in the region have created special economic zones (SEZs)

1 Draft version of this paper was presented at the "SmartEIZ conference", held from September 25 to 26, 2018 in Zagreb, within the project "Strengthening scientific and research capacity of the Institute of Economics, Zagreb (EIZ) as a cornerstone for Croatian socioeconomic growth through the implementation of Smart Specialisation Strategy". The Institute of Economics, Zagreb implemented the project in partnership with University College London - School of Slavonic \& East European Studies, University Bocconi, Center for Research on Innovation, Organization and Strategy, and Maastricht University, Maastricht Economic and Social Research Institute on Innovation and Technology (UNU MERIT). The project has received funding from the European Union's Horizon 2020 research and innovation programme under grant agreement No. 692191. 
to provide a more hospitable environment for FDI. ${ }^{2}$ Companies located within these zones benefit from exemptions to standard customs and tax rules, dedicated infrastructure, a regular supply of electricity, and reliable communications. For these reasons, the Final Declaration of the Western Balkans Summit in Vienna in 2015 supported the role of SEZs to foster the development of regional value chains in promoting exports and growth. ${ }^{3}$ The overall aim has been to integrate the economies into global value chains, and into the system of international vertical specialisation of production that has developed through the process of globalisation (Hummels, Ishii, \& Yi, 2001; Nordas, 2008).

At the same time, a regional policy instrument known as "smart specialisation" has been introduced within the EU (Morgan, 2017; Radosevic \& Stancova, 2018) designed to propel less developed regions on a path of innovation-based growth. The smart specialisation strategy (S3) is part of the Innovation Union Flagship Initiative, adopted in 2010 as a comprehensive innovation strategy for Europe to deliver smart, sustainable, and inclusive growth. ${ }^{4}$ It aims to enhance innovation and competitiveness by mobilizing domestic resources in specific areas and industries (Foray et al., 2012; Wyrwa, 2014). Adopting a national S3 strategy has become an ex-ante conditionality for member states to access EU Structural Funds from 2014 to 2020 (European Commission, 2012). As such, it is applicable to preaccession countries in the Western Balkans where its implementation is supported by the Regional Cooperation Council (Regional Cooperation Council, 2018). Moreover, the IPA II regulation setting out the parameters for EU assistance to the Western Balkan region specifically acknowledges the importance of smart specialisation as a thematic priority for assistance efforts (Matusiak \& Kleibrink, 2018). The EU's Joint Research Centre is supporting the development of policies in the field of smart specialisation through its Smart Specialisation Platform. ${ }^{5}$

2 SEZs are used as an instrument of economic development in many countries, and it is estimated that there are more than 4,300 zones in 130 countries (see Special Economic Zones, 2015).

3 Western Balkans Summit (2015).

4 For more information on the Innovation Union Flagship Initiative see http://ec.europa.eu/research/innovationunion/index_en.cfm

5 For more information on Smart Specialisation Platform see http://s3platform.jrc.ec.europa.eu/eu-enlargement 
The first two smart specialisation strategies in the region have been adopted in Montenegro and Serbia in 2019. As yet however, support for the development of these strategies focuses mostly on the development of research and innovation capacity, rather than engaging more widely with local industrial policies, such as those embodied in the framework of SEZs or other policies to attract and nurture foreign investment and associated technology transfer, and technology diffusion in the business sector. ${ }^{6}$

Smart specialisation is an integrated, place-based economic policy designed to shift resources into sectors with high economic potential (Foray et al., 2012). It aims to upgrade the knowledge base, technology and other complementary resources to support the integration of local production networks into global value chains (Georghiou, Elvira Uyarra, Saliba Scerri, Castillo, \& Cassingena Harper, 2014; Radosevic \& Stancova, 2018). The key focus is on identifying "smart" regional strategies that would enable specialisation in areas that encourage complementarities with the productive capabilities of a region. From the perspective of smart specialisation, the SEZs in the Western Balkans could be used as a device to build smart specialisation strategies by helping the businesses in local economies to specialise in selected sectors supported by demand from the foreign companies based in the SEZs. Most SEZ-based companies are innovation-driven companies offering opportunities for local firms to integrate in downstream innovation activities. This requires a certain level of technological capability which does not develop automatically, and public support is typically needed to build the needed competencies (Lauridsen, 2010). While the Western Balkan governments have developed incentive programmes to attract foreign investors, these policies have not included any serious efforts to support local businesses to develop the supply capacities needed to enable them to integrate into global value chains. Therefore, this article argues that future incentive packages should go hand in hand with measures to support local small and medium-sized

6 For example, see the various strategic documents on innovation policy such as "Research for Innovation: Strategy on Scientific Development of the Republic of Serbia for the period 2016-2020", Ministry of Education, Science and Technological Development of the Republic of Serbia, 2016, and the various unpublished reports of the Regional Cooperation Council on mapping the smart specialisation strategies in the Western Balkan countries. 
enterprises (SMEs). Moreover, specific FDI incentives should target sectors or industries that could be potential candidates for S3 strategies.

In this article, we assess the alignment of SEZ policies with the concept of smart specialisation in the region. ${ }^{7}$ We question the extent to which SEZ policies have supported local businesses in their integration into global value chains as a basis for smart specialisation. The main geographic focus of the article is on Serbia and North Macedonia, where SEZs have been most developed in the Western Balkans, although other countries in the region are closely following these developments and some aim to implement similar policies. The analysis is based on primary research carried out between November 2016 and May 2017, investigating the impact of SEZs on investment, productivity and exports in these two countries based on information gathered from administrative data and field interviews with SEZ-based companies and their suppliers. ${ }^{8}$ The article is structured as follows: section 2 describes the institutional framework of SEZs in the region, and the range of investment incentives that have been used to attract foreign investors. Section 3 analyses the overall economic performance of SEZs in terms of productivity, investment and international competitiveness, based mainly on evidence from Serbia where SEZs have been most developed. Section 4 analyses the impact of SEZs on the local economies in both countries, focusing on linkages to local suppliers, technology transfer and the development of workforce skills. Section 5 provides conclusions, reflecting on the relationship between the established policies focused on SEZs and the emerging policies based on smart specialisation.

7 A wide range of policies have been implemented around the world to attract foreign investors, including employment subsidies, export subsidies, $R \& D$ tax credits and $R \& D$ subsidies. However, in this article, we concentrate on the contrast between two of the main policies that are a focus of current policy debates in the Western Balkans in recent years: SEZ policies and S3 policies.

8 The fieldwork involved semi-structured interviews with policy makers, foreign investment agencies, business associations and foreign investor councils and with senior managers in SEZ-based companies. 


\section{Special Economic Zones Policies}

Special Economic Zones (SEZs) in the Western Balkans have mainly been established as export processing zones within duty-free areas that provide infrastructure and facilities for manufacturing activities aimed at export markets. A prominent example is the SEZ in Kragujevac in Serbia, which was established to support the Italian car-maker Fiat to regenerate the derelict Zastava car plant in Kragujevac. SEZs are called "Free Zones" in Serbia and "Technological Industrial Development Zones" in North Macedonia. The establishment of SEZs in these two countries has enabled foreign companies to sidestep the difficulties of dealing with poor infrastructure and unwieldy bureaucracies in the domestic markets and has become an important tool for attracting FDI.

The main distinction in the institutional design of SEZs is between a centralised approach, in which they are planned and financed by a central government agency, and a decentralised approach, in which local authorities create them within a legal framework set by the central government. The centralised approach focuses on the coordination of infrastructure, while the decentralised approach may better meet the needs of local communities and local business actors (Mohberg, 2015).

A decentralised design for SEZs has been adopted in Serbia, where local municipalities are empowered to establish a SEZ on their territory subject to authorisation by the Free Zone Administration established under the Law on Free Zones of 2006 (Government of Serbia, 2006). Municipal ownership ensures that local interests are taken into account. ${ }^{9}$ Altogether, 14 SEZs have been established in Serbia, many of which were developed on the basis of former local industrial zones. The number of companies located in SEZs increased from 173 in 2012 to 221 in 2017, an increase of 28 percent over the period. ${ }^{10}$

In Serbia, raw materials and equipment imported into a SEZ, and production carried out within it, are free of customs duties and VAT. Construction materials,

9 Ownership by municipalities is not universal; the SEZ in Kragujevac is owned by the Fiat motor company.

10 Data from annual reports of the Free Zone Administration in Belgrade, available on the website of the Ministry of Finance of the Republic of Serbia: http://www.usz.gov.rs/eng/index.php 
transport services and energy (electricity, gas, fuel, oil, coal) can be purchased free of VAT by SEZ-based companies. If goods produced in a SEZ are sold on the domestic market, appropriate VAT and customs duties must be paid, but there is still a cash flow advantage in being based in a SEZ. An example of the value of this exemption is that of Tigar Tyres at the SEZ in Pirot. The company imported new machines and equipment worth EUR 180 million exempted from VAT (a benefit worth EUR 36 million) and customs duties, and constructed its factory exempt from VAT on construction costs.

The Serbian Development Agency (RAS) provides investment subsidies to foreign investors located either inside or outside SEZs depending on the level of municipal development, investment size, and the number of jobs created. These subsidies are subject to negotiation with each investor individually, and the amount agreed upon is a commercial secret, so no data are available at individual company level. An additional negotiated subsidy is available for labour-intensive companies that employ more than 200 workers. Subsidies in the manufacturing sector may be granted for investment projects valued above EUR 100,000 that employ at least ten workers. The programme was set out in the Investment Law $^{11}$ and supplemented by the Decree on Terms and Conditions for Attracting Direct Investments (Government of Serbia, 2016) and further amending decrees in subsequent years. All large investors can benefit from an investment subsidy package (grants for eligible costs of investment, subsidies for new employment, and local subsidies). ${ }^{12}$ While the law is equally applicable to domestic and foreign companies, the aim is to attract foreign investors, and beneficiaries should be involved in international trade. The programme has benefited companies located both within and outside SEZs. In three municipalities (Kragujevac, Pirot and Užice) almost all RAS-subsidised investments from 2003 to 2016 were located

11 The Investment Law (Government of Serbia, 2015) replaced the previous laws on foreign investment by extending national treatment to foreign investors and eliminating discriminatory practices against foreign investors. It also allowed the transfer or repatriation of profits and dividends, provided guarantees against expropriation, allowed customs-duty waivers for equipment imported as capital-in-kind, and enabled foreign investors to qualify for government incentives.

12 The amount of subsidy is also related to the level of development of the municipality, with less developed municipalities receiving a larger subsidy. 
in SEZs, whereas in six municipalities (Apatin, Belgrade, Kruševac, Novi Sad, Smederevo and Vranje) almost all investments were located outside SEZs. Investors that have negotiated agreements with RAS received an average subsidy of EUR 9,000 per job created in 2014, EUR 7,000 in 2015, and EUR 5,000 in $2016 .{ }^{13}$ These subsidies are equivalent to about half of the total investment per employee in SEZs as shown in Table 1 below. The number of new jobs created under the programme increased from 5,000 in 2014, to 7,000 in 2015, and 17,000 in 2016.

In contrast, a centralised design has been adopted in North Macedonia where SEZs are under central state ownership. The Directorate for Technology Industrial Development Zones (DTIDZ) establishes and develops the SEZs and monitors and regulates users' activities. It grants construction permits, work permits and other assistance, signs contracts for the lease of land, and has its own budgetary funds. It also has responsibility for investment promotion in the SEZs, negotiating incentive contracts with prospective investors on behalf of the government and providing aftercare services for SEZ-based investors. It facilitates central government services such as licensing, land use, and provision of utilities, and monitors regulatory compliance. It is also responsible for regulating the rents, tariffs and fees charged to users, and for coordinating the processing of all required approvals and permits. Eight active SEZs that host 18 foreign companies have been established. Subsidies to attract high-tech FDI companies include 0 percent customs duties or VAT on imported goods or equipment (vs. the standard 18 percent); 0 percent profit tax for up to ten years (vs. the standard 10 percent); subsidies to build a factory up to EUR 500,000; employment subsidies up to 50 percent gross wage, and 50 percent of justified investment costs up to EUR 50 million. 


\section{Structure and Performance of SEZs}

Several international studies have demonstrated potentially positive impacts of SEZs on economic development. Wang (2013) found that export processing zones in China increased foreign direct investment without reducing domestic investment and had relatively low deadweight losses. Givord, Rathelot, and Sillard (2013) identified a positive impact of a tax exemption programme on the entry of new companies to enterprise zones in France. Ciżkowicz, Ciżkowicz-Pękała, Pękała, \& Rzońca (2015) identified a positive impact of SEZs on economic development in Poland, as did Ambroziak (2016) who found that state aid granted to entrepreneurs in SEZs has a positive impact on economic development in less-developed districts (poviats). Thus, there are some grounds for expecting a positive impact of SEZs on economic development.

However, this may depend on a host of conditioning country-specific factors. While SEZs may promote economic growth in the right institutional context, in the wrong institutional context they may lead to resource misallocation and facilitate rent-seeking behaviour (Mohberg, 2015). Since the institutional environment in the Western Balkans is often perceived to be weak, there is a need for further research on the impact of SEZs on economic development in this region to support the design of effective SEZ policies to raise productivity, investment and competitiveness. Frick, Rodriguez-Pose, and Wong (2019) argue, based on data analysis of SEZs in 22 developing countries, that the growth of SEZs can be hard to maintain over time, while using SEZs to support technology transfer widely throughout an economy can be problematic.

This section analyses the sectoral structure and performance of SEZs in Serbia based on data available from the annual reports of the Serbian Free Zone Administration that provide information about turnover, investment, exports, and imports of SEZ-based companies. ${ }^{14}$

14 Comparable data is not available to analyse the performance of SEZs in North Macedonia. The administrative body in charge, the TIDZ, does not provide data on a systematic and transparent basis that would allow a comparable analysis for the SEZs in that country. 


\subsection{Sectoral Structure}

Investment in SEZs in the Western Balkans has been especially significant in the motor car components industry (Shimbov, Alguacil, \& Suárez, 2016). In Serbia, for example, the largest exports are finished motorcars from SEZ Kragujevac, while other SEZs produce motorcar components including electrical motors, tyres, and other parts and accessories for motorcars. A relatively small part of SEZ exports consist of metal products, shoes, furniture, and plastic products. The focus on motorcar components reflects the integration of Serbian SEZs into the $\mathrm{EU}$ and global value chains in this sector.

Table 1: Shares of Main Export Products in Each SEZ's Total Exports, Serbia (in \%)

\begin{tabular}{|c|c|c|c|c|c|c|}
\hline SEZ location & 2012 & 2013 & 2014 & 2015 & 2016 & Exported products \\
\hline Apatin & 85.1 & 81.5 & 79.4 & 78.5 & 72.6 & $\begin{array}{l}\text { Alcoholic drinks, corn and beans, oil } \\
\text { seeds; shoes and knitted fabrics }\end{array}$ \\
\hline Beograd & 43.5 & 54.2 & 57.4 & 50.9 & 45.0 & $\begin{array}{l}\text { Edible products, medicines and } \\
\text { cosmetics }\end{array}$ \\
\hline Kragujevac & 93.1 & 94.7 & 91.9 & 91.4 & 91.6 & Automobiles \\
\hline Kruševac & -- & -- & 96.2 & 90.0 & 100.0 & $\begin{array}{l}\text { Inorganic chemicals, synthetic } \\
\text { rubber, regenerated rubber, waste } \\
\text { and tyres for automobiles }\end{array}$ \\
\hline Novi Sad & 0.0 & 18.9 & 28.2 & 55.7 & 70.0 & Petroleum products \\
\hline Pirot & 94.1 & 94.6 & 94.4 & 95.6 & 95.0 & Tyres for automobiles \\
\hline Šabac & -- & -- & 96.6 & 94.7 & 69.7 & Nails and screws \\
\hline Smederevo & & & 20.0 & 41.6 & 57.0 & Electrical equipment \\
\hline Subotica & 89.1 & 83.8 & 70.4 & 65.5 & 71.0 & Electrical motors \\
\hline Užice & 99.3 & 97.2 & 97.1 & 97.0 & 96.5 & Aluminium and copper \\
\hline Vranje & 46.7 & 41.3 & 34.6 & 33.4 & 42.7 & Furniture and shoes \\
\hline Zrenjanin & 0.0 & 92.0 & 92.2 & 91.8 & 88.1 & Electrical equipment \\
\hline
\end{tabular}

Source: Statistical Office of the Republic of Serbia (authors' calculations).

Most SEZs specialise in the production of one or a few export products (see Table 1). Five SEZs account for over 90 percent of all SEZ exports. Three of these have a high degree of specialisation in a single product, mainly in the motorcar industry (e.g. Kragujevac, Subotica, and Pirot). For example, 96 percent of the exports from the SEZ in Kragujevac consists of motorcars, 95 percent of the exports from 
the SEZ in Pirot consists of tyres for automobiles, and 97 percent of exports from Užice consists of the raw materials, aluminium, and copper. Some other SEZs are less specialised, such as the SEZ in Belgrade whose main exports of edible products, medicines, and cosmetics form only 45 percent of its total exports. Likewise, exports of furniture and shoes from the SEZ in Vranje account for only 45 percent of its total exports. Overall, the average degree of export specialisation is 75 percent, indicating that SEZs are closely intertwined to the international division of labour through their position in the EU and global value chains in the motorcar industry.

The high degree of specialisation can also be seen from the fact that only three product groups account for about two-thirds of exports from all SEZs in Serbia. These are motorcars (produced at Kragujevac), tyres (produced at Pirot) and electrical motors (produced at Subotica). ${ }^{15}$ This specialisation of production in relatively few product groups provides further evidence of the close integration of the SEZs into the EU and global value chains. This has played an important role in the revival of Serbia's exports and in the country's achievement in raising the share of goods exports in GDP to 35 percent in 2015, above the EU average of 32 percent of GDP.

\subsection{Productivity and Investment}

Both turnover and productivity per employee have been consistently higher in Serbian SEZs than in manufacturing industry as a whole (see Table 2). In 2017, turnover per employee in SEZs was 56.5 percent higher than for manufacturing industry, and productivity measured by gross value added (GVA) per employee was 41.7 percent higher. However, the performance of SEZ companies was on a downward trend. Average turnover per employee in the SEZs decreased by 23.0 percent between 2013 and 2017 (compared to an increase of 9.6 percent

15 While the production of motorcars has been falling since 2013, due to a lack of new investment in the production line and in the development of a new model, the gap has been partly made up by an increase in the production of tyres and electrical motors. 
in manufacturing as a whole), while productivity decreased by 18.4 percent (compared to an increase of 9.2 percent in manufacturing as a whole). This trend may reflect the perverse incentives of the employment subsidies granted to foreign investors, motivating them to adopt relatively labour-intensive production technologies, thus undermining productivity growth.

Table 2: Performance Indicators in Serbian SEZs (Free Zones) and in the Serbian Manufacturing Sector as a Whole (EUR)

\begin{tabular}{|c|c|c|c|c|c|c|}
\hline \multicolumn{2}{|l|}{ Indicator } & 2013 & 2014 & 2015 & 2016 & 2017 \\
\hline \multirow{2}{*}{$\begin{array}{l}\text { Turnover per } \\
\text { employee }\end{array}$} & SEZs & 225,140 & 236,235 & 186,461 & 191,543 & 173,441 \\
\hline & Manufacturing sector & 101,102 & 103,652 & 107,151 & 108,030 & 110,836 \\
\hline \multirow{2}{*}{$\begin{array}{l}\text { Productivity (GVA } \\
\text { per employee) }\end{array}$} & SEZs & 118,350 & 129,155 & 106,034 & 106,629 & 96,573 \\
\hline & Manufacturing sector & 62,417 & 63,494 & 65,291 & 83,798 & 68,133 \\
\hline \multirow{2}{*}{$\begin{array}{l}\text { Investment per } \\
\text { employee }\end{array}$} & SEZs & 13,078 & 8,076 & 9,464 & 9,391 & 7,599 \\
\hline & Manufacturing sector & 4,753 & 3,214 & 3,244 & 3,483 & 3,807 \\
\hline \multirow{2}{*}{$\begin{array}{l}\text { Investment rate } \\
\text { (investment/GVA) }\end{array}$} & SEZs & $11.1 \%$ & $6.3 \%$ & $8.9 \%$ & $8.8 \%$ & $7.9 \%$ \\
\hline & Manufacturing sector & $5.1 \%$ & $5.0 \%$ & $4.2 \%$ & $5.6 \%$ & $7.6 \%$ \\
\hline
\end{tabular}

Notes: Sales are on both foreign and domestic markets; gross value added (GVA) is calculated as the difference between turnover and imports.

Sources: Free Zone Administration Annual Reports, authors' calculations, Serbia Agency for Business Registers, Statistical Office of the Republic of Serbia.

The high level of investment per employee in SEZs in 2013 was partly due to the large investment made by Fiat in setting up its production line at the SEZ in Kragujevac. This company ${ }^{16}$, which is under two-thirds Italian ownership and one-third Serbian state ownership, has invested a total of EUR 1.3 billion at Kragujevac, of which EUR 1.0 billion was for the purchase of modern production equipment exempted from customs duties and VAT (a benefit worth EUR 200 million). As a result of this high initial investment, overall investment per employee in Serbian SEZs was EUR 13,078 in 2013, but thereafter it fell to EUR 7,599 in 2017. The huge contribution of Serbian state subsidies to the companies in the SEZs can be seen from the fact that the investment per employee in the SEZs in 2017 was about one and a half times the value of the per-job employment subsidy

16 The full name of the company is Fiat Chrysler Automobiles d.o.o. 
granted to new investors by RAS. In other words, the Serbian state has been subsidising the investment costs of SEZ-based companies to the tune of about two-thirds of the total cost. Consequently, it is not surprising that investment per employee in the SEZs was double that in manufacturing industry as a whole. Despite this, the investment rate in the SEZs, measured as the share of investment in GVA, declined from 11.1 percent in 2013 to 7.9 percent in 2017, while in contrast the investment rate in the manufacturing sector as a whole actually increased from 5.1 percent in 2013 to 7.6 percent in 2017. Thus, the marginal effectiveness of the employment subsidies in stimulating investment in SEZs has gradually disappeared. ${ }^{17}$

\subsection{Exports and Imports}

Exports from SEZs have formed a substantial part of the Serbian economy's export boom in recent years, accounting for 13.3 percent of total exports in 2017. ${ }^{18}$ Exports per employee were substantially higher than in the manufacturing industry as a whole, reflecting the aim of the SEZ policy to contribute to the export-led growth of the Serbian economy (see Table 3). Nevertheless, exports per employee have stagnated in the SEZs, reflecting the overall absence of labour productivity growth reported in the previous section, possibly due to the perverse incentives effects of the employment subsidies offered to foreign investors.

The main aim of the Serbian SEZ policy has been to boost the competitiveness of exports. This seems to be successful, as the share of exports in GVA in SEZs averaged 73.9 percent over the period from 2013 to 2017, compared to just 50.4 percent for manufacturing industry as a whole. Moreover, this indicator increased by 15.3 percentage points in the SEZs over this period compared to just 8.6 percentage points for the whole of manufacturing industry. The relatively low share of exports in GVA in the early years of the SEZ experience suggests

17 Economic growth has recovered in recent years. After a decade of slow or stagnant growth, the economy began to grow in 2016 supported by increased foreign direct investments, and exports (Bartlett, 2018).

18 Total exports from Serbian SEZs increased from EUR 2.164 billion in 2013 to EUR 2.262 billion in 2017, while imports decreased from EUR 2.242 billion to EUR 2.180 billion. 
that a relatively large component of value added may have been related to the construction of factories within the SEZs or to sales on the domestic market.

Table 3: International Trade of Serbian SEZs and Manufacturing Industry (2013-2017)

\begin{tabular}{|c|c|c|c|c|c|c|}
\hline \multicolumn{2}{|l|}{ Indicator } & 2013 & 2014 & 2015 & 2016 & 2017 \\
\hline \multirow{2}{*}{$\begin{array}{l}\text { Exports per } \\
\text { employee (EUR) }\end{array}$} & SEZs & 79,656 & 85,567 & 75,350 & 87,679 & 79,752 \\
\hline & Manufacturing sector & 31,419 & 33,519 & 35,580 & 37,987 & 40,113 \\
\hline \multirow{2}{*}{ Exports/GVA } & SEZs & $67.3 \%$ & $66.3 \%$ & $71.1 \%$ & $82.2 \%$ & $82.6 \%$ \\
\hline & Manufacturing sector & $50.3 \%$ & $52.8 \%$ & $54.5 \%$ & $45.3 \%$ & $58.9 \%$ \\
\hline \multirow{2}{*}{$\begin{array}{l}\text { Import intensity } \\
\text { (Imports/Exports) }\end{array}$} & SEZs & $209.0 \%$ & $134.1 \%$ & $125.1 \%$ & $106.7 \%$ & $96.8 \%$ \\
\hline & Manufacturing sector & $151.1 \%$ & $123.1 \%$ & $119.8 \%$ & $111.2 \%$ & $81.2 \%$ \\
\hline \multirow{2}{*}{$\begin{array}{l}\text { Import dependence } \\
\text { (Imports/Turnover) }\end{array}$} & SEZs & $47.4 \%$ & $45.3 \%$ & $43.1 \%$ & $44.3 \%$ & $44.3 \%$ \\
\hline & Manufacturing sector & $38.3 \%$ & $38.7 \%$ & $39.1 \%$ & $39.1 \%$ & $38.5 \%$ \\
\hline
\end{tabular}

Note: GVA = gross value added.

Sources: Free Zone Administration Annual Reports, authors' calculations, Statistical Office of the Republic of Serbia.

At the same time, the import intensity of production in SEZs (measured by the import/export ratio) is extremely high at 96.8 percent in 2017, although falling (see Table 3). An example in practice is the case of the Belgian company Metech based at the SEZ in Smederevo, which imported, in 2017, 80 percent of its raw materials from Belgium and exported 95 percent of the final product back to Belgium to the parent company Metes. With such a high overall import intensity of production, it is unlikely that there is much indirect spill-over to the local economy through backward linkages to local suppliers. Most of the effect is likely to come from direct employment, much of which, as explained above, is subsidised by the state through the employment subsidy scheme managed by the RAS. It could be questioned whether this model of attracting FDI is likely to be a strong driver of economic growth and development in the future. The import intensity of the Serbian manufacturing sector is lower than in SEZs, but is nevertheless very high, indicating that this is a general problem not confined to SEZs, but also reflecting the import intensity of subsidised foreign investors based outside the SEZs. 
Table 3 also casts light on the overall degree of import dependency of the Serbian economy (measured by the ratio of imports to turnover). Not surprisingly, this is substantially higher in the SEZs, whose business model involves processing imported products for onward export to foreign markets, than in the manufacturing sector as a whole. The import dependency of the latter at 38.5 percent in 2017 is similar to the Croatian economy with an import dependency ratio of 30.4 percent for the whole economy, and 38.6 percent for exports (Mikulić \& Lovrinčević, 2016).

Little data is available for the case of North Macedonia, since the Directorate for Technological Industrial Development Zones, the centralised agency responsible for SEZ policy in the country, is unwilling to release reliable data on the performance of companies based within the zone network. Press reports indicate that SEZs have made a significant contribution to exports, accounting for an estimated 35 percent of the country's total exports in 2016. ${ }^{19}$ Within this, exports of machinery and transport equipment alone accounted for 30 percent of total exports. Some individual companies based in SEZs have made substantial contributions to export earnings for the economy as a whole. This can be identified indirectly from sectoral trade data. For example, the export product group "supported catalysts with precious metal or precious metal compounds as the active substance" accounted for 16.4 percent of all the country's exports in $2015 .{ }^{20}$ Johnson Matthey, based in the SEZ Skopje 1, is the sole producer of these catalytic converters. It is notable that almost all of the production carried out in SEZs is destined for the export market. 


\section{SEZs and the Local Economy}

One of the main advantages claimed for SEZs is that by attracting additional foreign investment into a locality, they raise the technological and skill levels in the local economy through knowledge spill-overs, backward linkages, technology transfer, and technological upgrading of local firms (Hansen \& Birkinshaw, 2007; Jenkins \& Arce, 2016). In addition, local companies that supply SEZ-based companies may broaden their activity to become strategic suppliers within a wider global value chain, expanding to international markets (Johansson \& Nilsson, 1997). However, the successful integration of local firms into global value chains requires broad support to the local business sector aimed at developing its production capacity (Farole \& Akinci, 2011). Such broader programmes should promote skill development, training, and knowledge sharing; they should promote links with zone-based firms and support the integration of regional value chains. This is the essence of smart specialisation at the local level. However, policy measures of this type to encourage and support positive spill-over effects from SEZs to local economies have been largely absent in the Western Balkans. As shown in this section, we find only limited evidence of such effects beginning to emerge from the activity of the SEZs in North Macedonia and Serbia. We base our analysis on a series of qualitative in-depth interviews with managers of SEZ-based companies and their suppliers, carried out in both countries in 2017. The emphasis in this section is on the case of North Macedonia, since reliable statistical data on the performance of the foreign investor companies were not available for reasons described in the previous section.

\subsection{Local Suppliers}

In North Macedonia, local businesses are only slowly developing their capacity to supply foreign companies based in SEZs. ${ }^{21}$ Most business services, such as legal services, are procured locally, but the supply of inputs to the production process 
is far less well-developed. This process is assisted by the central administrative authority, the DTIDZ, which provides a list of local suppliers to foreign companies based in SEZs. According to the Macedonian Foreign Investors' Council, about 500 local companies supply foreign companies based in SEZs. However, although many SEZ-based companies would like to purchase more inputs directly from local suppliers, due to their cost and location advantages, such suppliers are mostly unable to provide the required quality and quantity of inputs.

Most SEZ-based companies in North Macedonia import their supplies from abroad. This is partly due to the inability of local suppliers to produce inputs that meet the required technical and safety standards of foreign companies, as well as to the ease of importing inputs from lower-cost suppliers abroad (International Monetary Fund, 2015a). ${ }^{22}$ There are numerous examples of this. For example, Adient Seating, based in the SEZ in Štip ${ }^{23}$, obtains all its inputs from foreign companies whose product quality has been approved by global customers such as Mercedes and Ford. Local companies are usually only contracted for tooling, construction work, maintenance services, and transportation. Another SEZ-based foreign company called Technical Textiles obtains its supplies from China and the $\mathrm{EU}$, while its local supply is limited to spare parts, packaging, tooling, cartons, support and maintenance services, transport, and construction. A US company, Lear, imports all its raw materials from Moldova, Poland, and Ukraine, and also exports to these countries.

There are a few success stories of local companies supplying inputs to the foreign companies based in SEZs. One of these, Uniplast, is a supplier to Van Hool in SEZ Skopje 2. Starting from a small contract, the company satisfied Van Hool with the quality of its products and went on to win additional contracts to supply components for the buses produced in the SEZ. Employment in Uniplast increased from 12 employees in 2012 to 43 employees in 2017. Similarly, another

22 A recent IMF report observed that "[a]necdotal evidence suggests that the development of backward linkages between big foreign investors and potential domestic suppliers has been limited, largely owing to the inability of producers to meet the technical and safety requirements needed to export towards the EU." (International Monetary Fund, 2015a, p. 11).

23 Author interview with senior manager, Adient Seating, Štip, February 2017. 
supplier, TE-TE Plast in Struga, successfully sells components to SEZ-based companies KEMET, Van Hool, and Johnson Matthey.

Some initiatives have been taken to try to boost the linkages between the SEZ companies and the local economies. In Ilinden municipality, in Skopje, the mayor has established a "Forum for Business" to bring together local and foreign companies, schools, and the community. Several companies from the local SEZ Skopje 2 are members of this forum, including Johnson Controls, Van Hool, and others. However, most municipalities are not so helpful to the local business sector. In Struga, for example, a supplier company reported that the local municipality is not at all supportive. Although its factory is located on state-owned land, the supply of electricity is unreliable, and the municipality has failed to provide a connection to the electricity grid. ${ }^{24}$

In response to the scarce availability of local suppliers, some foreign companies aim to develop the local supply chain themselves in order to meet their needs for reliable high-quality supplies from local sources. One example is the SEZbased company Delphi which currently purchases components exclusively from suppliers in Japan, Taiwan, and South Korea. However, it intends to use more local suppliers in the future and plans to help them increase the volume and quality of their products. Another example is Van Hool, which sources most of its supplies from Spain, Germany, Romania, and Turkey, due to the low capacity and quality of local suppliers, but aims to develop local suppliers to meet the required standards. ${ }^{25}$

In Serbia, the local supply chain is also very weak. For example, in the SEZ in Subotica, in the Vojvodina region in the north of Serbia, hardly any SEZ-based companies contract with local suppliers, due to their low technological level and high prices. Local companies mostly provide only security, maintenance, construction, and packaging services. In 2015, the German Chamber of Commerce $(\mathrm{AHK})$ launched a call for 100 local suppliers and together with

24 Author interview with senior manager, Uniplast, Struga, February 2017.

25 Author interview with senior manager, Van Hool, Skopje 2 SEZ, February 2017. 
the Subotica municipality organised an event for local supply companies. Only 14 companies from all over the country met the qualification criteria. Siemens also published a call for suppliers, but received no replies at all. In the SEZ in Novi Sad, the capital of the Vojvodina region, SEZ-based companies have found it difficult to identify local suppliers, even from elsewhere in the country. ${ }^{26}$ In response to the limited local supply capacity, the Serbian Development Agency has made an effort to provide support for the development of local supply chains alongside support for SME exporters, clusters, networks, and quality standards.

There are some exceptions. One of these is a company called Energomont, a local supplier company near Subotica with about 100 employees, which provides inputs to Siemens. Some other examples of supplier linkages with SEZ-based companies can be found in the large SEZ in Pirot in the south of Serbia, although the most important of these domestic companies are themselves located within the SEZ, and the majority of raw materials are imported from abroad. In the SEZ in Kragujevac, in the centre of Serbia, two local companies, Adler and Goma Line, supply parts to Fiat. However, about two-thirds of the components for the production of Fiat motorcars are produced by a few Italian supplier companies that are themselves located within the SEZ.

\subsection{Technology Transfer}

Foreign companies based in SEZs are often engaged in processing activities, turning intermediate products either into final products or into more advanced intermediate products within a global value chain. The inputs into the manufacturing process may be obtained from abroad or from local suppliers. As noted in the previous section, where local suppliers are used, producers require an appropriate level of quality. To achieve this, foreign investors in SEZs may transfer up-to-date technologies to their local suppliers either in the form of machinery or knowledge with the aim of raising productivity of their supplier 
and reducing the costs of locally sourced inputs (Blalock \& Gertler, 2008). The diffusion of new technologies may in turn induce the entry of new local suppliers, raise competition in the local market, and further reduce input prices for SEZ companies. In our field research we identified some examples where technology transfer to local suppliers is beginning to take place in the Western Balkans.

In North Macedonia, very little technology transfer resulting from cooperation between SEZ-based foreign companies and their local suppliers was observed in our field research. There are a few notable exceptions. For example, the local supplier company Aktiva, which produces parts for Van Hool and Johnson Controls, has invested heavily in robotic welding equipment to produce components specifically designed for Van Hool. It has obtained various international quality certificates and is in a position to work with other international companies. New contracts have been won on the basis of the work carried out for Van Hool, showing that Aktiva has benefited from reputational and network linkage effects, and as a result it has also managed to develop its own network contractors. Following this positive experience, Van Hool has developed a strategy for upgrading the production capacities of other local suppliers through access to finance for investment in improved production capacities.

A few examples of technological upgrading can also be found among the supplier companies themselves. For example, TE-TE Plast collaborated with SEZ-based KEMTA to raise quality standards. Having worked for five months on improving the quality of one small component, the company invested in new equipment to raise the technological level of the company. ${ }^{27}$ Another local supplier company acquired welding certificates compliant with EU standards and opened a separate welding training centre in 2013 to meet its own needs, supplying its centre with training materials, books and equipment.

In Serbia, as noted above, SEZ companies have relatively few local suppliers, so technology transfer is more limited. Suppliers have to meet the necessary standards and technical requirements and must offer competitive prices. There are 27 Author interview with senior manager, TE-TE Plast, Skopje, February 2017. 
a few examples of SEZ companies transferring technologies to supplier companies to enable them to meet the required quality standards. A rare exception, where technology transfer has taken place, was found in Subotica where Dunkermotoren has established a small R\&D centre for its global operations involving local supplier companies.

\subsection{Workforce Skills}

Access to skilled labour has influenced the location decision of some companies. The US company Lear, which produces car seat covers in the SEZ in Tetovo in North Macedonia, decided to locate there, due to the availability of skilled labour alongside the investment incentives offered. ${ }^{28}$ Similarly, the company Aktiva decided to locate in the SEZ in Štip to access the skilled local workforce, and the US company Kemet at Bunardžik SEZ listed the availability of skilled low-cost labour as the most important attraction factor for locating there. ${ }^{29}$ Yet, in both North Macedonia and Serbia the skills of many workers have deteriorated, due to long periods of inactivity and unemployment. As SEZ-based companies continue hiring from the available supply of skilled workers, skill shortages are emerging in some localities. The largely unreformed and unmodernised vocational education systems use outdated curricula, while higher education graduates also lack the skills needed for employment by foreign companies (Bartlett \& Uvalić, 2018). The increase in demand for labour from SEZ-based companies has begun to drive up the wages of skilled workers in some localities. In North Macedonia, some SEZ companies attract skilled workers by offering a "thirteenth wage", putting competitive pressure on local companies. In the SEZ in Ilinden municipality in Skopje, some categories of skilled workers earn more within the SEZ than outside it, ${ }^{30}$ and in Štip, average salaries have increased since companies started operating in the SEZ. Similarly, in Pirot in Serbia, SEZ-based companies have increased 
salaries for their skilled employees leading to tough competition between local and foreign firms. ${ }^{31} \mathrm{~A}$ sign of a tightening labour market is also seen in the strikes that took place at the SEZ in Kragujevac in June 2017, where workers felt empowered to seek higher wages through industrial action. ${ }^{32}$

In response to emerging skill shortages, some SEZ-based companies have provided additional training for their workers. The company Kemet regularly sends workers abroad for a six-month training in Germany, Italy, and the UK. Makedonka sends its employees to Slovakia for training. Van Hool in the Skopje 2 SEZ sent a group of engineers, supervisors, and managers to receive specialised training at the parent company in Belgium. ${ }^{33}$ In the SEZ in Smederevo in Serbia, operators from Rosa Catena, a company that produces chains from steel plate, were sent to Italy for training.

Some SEZ-based companies have set up their own training facilities. In the SEZ in Kavadarci in North Macedonia, a foreign company provides training in a school specifically established by the company for this purpose. In the SEZ in Kragujevac in Serbia, Fiat has established its own training centre, and in Subotica, Dunkermotoren plans to establish a similar one. Using a slightly different approach, Van Hool in the Skopje 2 SEZ has contracted a training company to deliver training to its workforce and has established an accredited training centre to train and certify welding professionals in collaboration with the Macedonian Employment Agency. A third model can be found in the SEZ in Novi Sad, where the city administration has cooperated with the National Employment Agency to develop the local workforce skills in response to shortages of engineers and technical professionals.

SEZ-based companies have also begun to develop cooperative links with local vocational schools to modernise the curricula and ensure a steady supply of appropriately skilled workers to meet future demand. For example, in North

31 Author interview with senior official, Pirot municipality, March 2017.

32 As reported by Reuters (Fiat, government, unions, 2017).

33 Author interview with senior manager, Van Hool, Skopje 2 SEZ, February 2017. 
Macedonia, Kemet has signed a Memorandum of Understanding with a school in the Ilinden municipality to create a study programme in ICT, electronics and automotive technologies. It has pledged to hire all 35 students from this programme after four years of schooling. Companies in the SEZ in Štip similarly cooperate with the School of Electro-Technical Engineering. ${ }^{34}$ Another example is Van Hool, which collaborates with local vocational schools to deliver part of a study programme on the company premises. Van Hool has also launched a programme for adult education to improve the skills of local workers. ${ }^{35}$ In Subotica in Serbia, several schools have responded to requests from SEZ-based companies to introduce new study programmes. ${ }^{36}$ For example, the secondary vocational school Ivan Sarić has signed contracts with SEZ-based companies to introduce a "dual" system of vocational education. ${ }^{37}$ This school cooperates with the SEZ-based companies Continental and Calzedonia to provide work-based learning opportunities, and cooperates with Swarovski on a study programme that maintains the tradition of teaching jewellery-making at the school. In the SEZ in Pirot, several companies cooperate with local vocational schools, one of which has introduced a new study programme on freight forwarding. In the SEZ in Smederevo, Metech invests one-tenth of its profits in educational projects at a local technical secondary school, whose students receive training in the company; it has also donated equipment and machines to the school.

Serbia also has a network of post-secondary technical colleges that are well-placed to collaborate with SEZ-based companies. In SEZ Subotica, Dunkermotoren cooperates with the local technical college on a three-year vocational study programme, providing a machine to the college for practical instruction. It has also employed a dozen engineers from the college as researchers and numerous workers have been enrolled on a training programme at the college. In the SEZ

34 Author interview with senior official, municipality of Štip, February 2017.

35 Author interview with senior manager, Van Hool, Skopje 2 SEZ, February 2017.

36 Author interview with senior manager, SEZ Subotica Management Company, March 2017.

37 The German aid agency GIZ supports such initiatives by organising the training of mentors within companies, while the companies provide scholarships to the students. 
in Kragujevac, Fiat cooperates with the local technical college to which it has donated a robot machine.

SEZ-based companies have also begun to develop cooperative links with universities. In North Macedonia, a company in the SEZ Skopje 1 has developed strong cooperative links with the University of St. Cyril and Methodius in electromechanics and engineering; it has also organised a study visit to a technical centre in Krakow in collaboration with the university. Van Hool offers scholarships for engineering students at the university. In the SEZ in Štip, the local supplier company Aktiva cooperates with the local Textile University. ${ }^{38}$ In Serbia, Fiat cooperates with the University of Kragujevac, providing work-based learning opportunities for students and jobs for graduates. In the SEZ in Pirot, companies cooperate with universities in Belgrade, Nišs, and even in Sofia in Bulgaria.

Supplier companies have also begun to take steps to improve the skills of their workers. For example, Uniplast in Struga has established a training programme in its own training centre in cooperation with the Ministry of Education and the Employment Agency. The accredited training programme enrols 20 students each year on a four-month course that combines theoretical and practical training in a workshop setting. The company has made this investment in training capacity in the context of fierce competition for skilled workers who are paid higher wages in the SEZ than in the local labour market. This competition is seen as unfair by many local companies, because the foreign companies that operate in the SEZ are exempt from paying corporate and personal income tax, and so have a competitive advantage compared to the local companies in the municipality. ${ }^{39}$

38 Author interview with senior official, municipality of Štip, February 2017.

39 Author interview with senior manager, Uniplast, Struga, February 2017. 


\section{Conclusion}

Both North Macedonia and Serbia have made significant progress in attracting foreign investors to SEZs, but at a high cost in subsidies. Many new jobs have been created and some improvements in export competitiveness have occurred, but there is little evidence of labour productivity growth or widespread technology spill-over, while the import intensity of production is extremely high, implying minimal linkage to local economies. With some exceptions, few SEZ-based companies source their inputs locally. Correspondingly, local companies find it difficult to supply foreign companies in SEZs, due to their limited production capacities and the large technology gap between them, a factor that is not sufficiently addressed by incentive programmes to attract foreign investors to SEZs.

Governments have tended to use SEZ policies as an alternative to regional and local development policies based on smart specialisation and have neglected policies that would develop the capacities of local businesses to engage with SEZ-based companies linked to global value chains. This may be related to the greater opportunities for rent-seeking where policies are based on centralised nontransparent provision of subsidies to foreign investors, instead of decentralised and transparent local business development through a smart specialisation strategy. So far, SEZ investments have been highly concentrated in the motorcar industry, suggesting an obvious sectoral focus for future smart specialisation strategies. Although some isolated attempts to upgrade the technological and quality level of local suppliers in this sector, governments would be well advised to provide greater support to local SMEs in this and other identified sectors to expand their capacity to supply inputs to SEZ-based companies. This could involve upgrading the technological level of local suppliers and providing fiscal support to local SMEs rather than focusing state subsidies on large foreign investors.

The growing demand for skilled labour has led to local labour shortages and is beginning to drive up wages in some sectors. In response, some SEZ-based 
companies are sending their employees abroad for training, while others cooperate with local schools, colleges and universities to increase supply of skilled workers. Governments could do more to develop this nascent cooperation between SEZbased companies and local educational institutions in order to boost the supply of skilled labour. Vocational education should be reformed and modernised, and state expenditure on retraining of unemployed workers should be expanded. This approach would require developing the vocational education and training systems and higher education systems around priorities better aligned to the needs of the evolving labour market.

Beyond the national level, Western Balkan countries should work together to develop a regional smart specialisation strategy to replace existing national industrial policies based on employment subsidies. Although there will inevitably be competition between individual economies to attract FDI, there is a role for cooperation to increase the regional supply base. Smart specialisation strategies should aim to develop support programmes and packages that would link SMEs to SEZ-based foreign investors on a regional basis, prioritising measures to increase in labour productivity. The research reported in this article suggests that such a regional smart specialisation strategy for the Western Balkans would be well advised to seek to identify priority areas for coordinated investment in industries such as motorcars and components, in which technologically advanced SEZ-based companies have strong connections to global value chains. 


\section{Literature}

Ambroziak, A. A. (2016). Income tax exemption as a regional state aid in Special Economic Zones and its impact upon development of Polish districts. Oeconomica Copernicana, 7(2), 245-267. doi: 10.12775/OeC.2016.015

Bartlett, W. (2018). Economic reforms in Serbia and prospects for economic recovery and growth. In R. Osbild \& W. Bartlett (Eds.), Western Balkan economies in transition: Recent economic and social developments (pp. 147-164). Berlin: Springer.

Bartlett, W., \& Uvalić, M. (2018). Higher education and the graduate labour market in the Western Balkans. In R. Osbild \& W. Bartlett (Eds.), Western Balkan economies in transition: Recent economic and social developments (pp. 47-60). Berlin: Springer.

Blalock, G., \& Gertler, P. J. (2008). Welfare gains from Foreign Direct Investment through technology transfer to local suppliers. Journal of Industrial Economics, 74(2), 402-421. doi: 10.1016/j.jinteco.2007.05.011

Ciżkowicz, P., Ciżkowicz-Pękała, M., Pękała, P., \& Rzońca, A. (2015). The effects of special economic zones on employment and investment: A spatial panel modelling perspective. Journal of Economic Geography, 17(3), 571-605. doi: $10.1093 /$ jeg/lbw028

Estrin, S., \& Uvalić, M. (2014). FDI into transition economies: Are the Balkans different? Economics of Transition, 22(2), 281-312. doi: 10.1111/ecot.12040

Estrin, S., \& Uvalić, M. (2016). Foreign direct investment in the Western Balkans: What role has it played during transition? Comparative Economic Studies, 58(3), 455-483. doi: 10.1057/ces.2016.10

European Commission (2012). Guide to Research and Innovation Strategies for Smart Specialisation (RIS 3). Brussels: Smart Specialisation Platform. doi: https://s3platform.jrc.ec.europa.eu/documents/20182/84453/RIS3+Guide.pdf/ fceb8c58-73a9-4863-8107-752aef77e7b4 
Farole, T., \& Akinci, G. (Eds.). (2011). Special economic zones: progress, emerging challenges, and future directions. Washington, DC: The World Bank. Retrieved from: https://openknowledge.worldbank.org/bitstream/handle/10986/2341/638 440PUB0Exto00Box0361527B0PUBLIC0.pdf?sequence $=1$ \&isAllowed $=y$

Foray, D., Goddard, J., Beldarrain, X. G., Landabasco, M., McCann, P., Morgan, K., Nauwelaers, C., \& Ortega-Argiles, R. (2012). Guide to research and innovation strategies for smart specialisation (RIS 3). Luxembourg: Publications Office of the European Union.

Fiat, government, unions agree on a wage rise in Serbia-based plant. (2017, 24 July). Reuters. Retrieved from: https://www.reuters.com/article/fiatserbia/fiat-government-unions-agree-on-wage-rise-in-serbia-based-plantidUSL5N1KF1WB

Frick, S. A., Rodriguez-Pose, A., \& Wong, M. D. (2019). Toward economically dynamic Special Economic Zones in emerging countries. Economic Geography, 95(1), 30-64. doi: 10.1080/00130095.2018.1467732

Georghiou, L., Elvira Uyarra, A., Saliba Scerri, R., Castillo, N., \& Cassingena Harper, J. (2014). Adapting smart specialisation to a micro-economy: The case of Malta. European Journal of Innovation Management, 17(4), 428-447. doi: 10.1108/EJIM-03-2014-0026

Givord, P., Rathelot, R., \& Sillard, P. (2013). Place-based tax exemptions and displacement effects: An evaluation of the Zones Franches Urbaines programme. Regional Science and Urban Economics, 43(1), 151-163. doi: 10.1016/j. regsciurbeco.2012.06.006

Hansen, M. T., \& Birkinshaw, J. (2007). The innovation value chain. Harvard Business Review, 85(6), 121-130.

Hummels, D., Ishii, J., \& Yi, K-M. (2001). The nature and growth of vertical specialization in world trade. Journal of International Economics, 54(1), 75-96. doi: 10.1016/S0022-1996(00)00093-3 
Government of Serbia. (2006). Law on special economic zones. Official Gazette of the Republic of Serbia, No. 26/2006.

Government of Serbia. (2015). Investment Law. Official Gazette of the Republic of Serbia, No. 89/2015.

Government of Serbia. (2016). Decree on terms and conditions for attracting direct investments. Official Gazette of the Republic of Serbia, No. 110/2016.

International Monetary Fund. (2015a). Former Yugoslav Republic of North Macedonia: Selected issues. Export competitiveness in North Macedonia. IMF Country Report No. 15/243, Washington, DC: International Monetary Fund. Retrieved from: https://www.imf.org/ /media/Websites/IMF/imported-full-textpdf/external/pubs/ft/scr/2015/_cr15243.ashx

International Monetary Fund. (2015b). IMF executive board completes first review under the policy coordination instrument for the Republic of Serbia. Press Release No. 18/491, Washington, DC: International Monetary Fund. Retrieved from: https://www.imf.org/en/News/Articles/2018/12/19/pr18491-republic-ofserbia-imf-executive-board-completes-first-review-under-the-pci

Jenkins, M., \& Arce, R. (2016). Do backward linkages in export processing zones increase dynamically? Firm-level evidence from Costa Rica. Journal of Business Research, 69(2), 400-409. doi: 10.1016/j.jbusres.2015.06.045

Johansson, H., \& Nilsson, L. (1997). Export processing zones as catalysts. World Development, 25(12), 2115-2128. doi: 10.1016/S0305-750X(97)00103-4

Lauridsen, L. S. (2010). Strategic industrial policy and latecomer development: The what, the why and the how. Forum for Development Studies, 37(1), 7-32. doi: $10.1080 / 08039410903558244$

Kalotay, K. (2013). Inward FDI in the Western Balkans in the wake of Croatia's accession. The Journal of World Investment and Trade, 14(2), 241-263. doi: 10.1163/22119000-01402001 
Matusiak, M., \& Kleibrink, A. (Eds.). (2018). Supporting an innovation agenda for the Western Balkans: Tools and methodologies. Luxembourg: Publications Office of the European Union.

Mikulić, D., \& Lovrinčević, Ž. (2018). The import content of Croatian economic sectors and final demand. Economic Research - Ekonomska Istraživanja, 31(1), 2003-2023. doi: 10.1080/1331677X.2018.1480967

Mohberg, L. (2015). The political economy of special economic zones. Journal of Institutional Economics, 11(1), 167-190. doi: 10.1017/S1744137414000241

Morgan, K. (2017). Nurturing novelty: Regional innovation policy in the age of smart specialisation. Environment and Planning C: Politics and Space, 35(4), 569-583. doi: 10.1177/0263774X16645106

Murgasova, Z., Ilahi, N., Miniane, J., Scott, A., \& Vladkova-Hollar, I. (2015). The Western Balkans: 15 years of economic transition. Regional economic issues special report. Washington, DC: The International Monetary Fund. Retrieved from: https://www.imf.org/external/pubs/ft/reo/2015/eur/eng/pdf/erei_sr_030915.pdf

Nordas, H. K. (2008). Vertical specialisation and its determinants. Journal of Development Studies, 44(7), 1037-1055. doi: 10.1080/00220380802150813

Organisation for Economic Co-operation and Development. (2016). Competitiveness in the South East Europe: A policy outlook. Paris: Organisation for Economic Co-operation and Development.

Organisation for Economic Co-operation and Development. (2017). Tracking the special economic zones in the Western Balkans: Objectives, features and key challenges. Paris: Organisation for Economic Co-operation and Development.

Radosevic, S., \& Stancova, K. C. (2018). Internationalising smart specialisation: Assessment and issues in the case of EU new member states. Journal of the Knowledge Economy, 9(1), 263-293. doi: 10.1007/s13132-015-0339-3 
Regional Cooperation Council. (2018). Multi-annual action plan for a Regional Economic Area (REA). Economies at a glance: State of play and way forward. Sarajevo: Regional Cooperation Council. Retrieved from: https://www.rcc.int/ priority_areas/39/map-rea

Sanfey, P., Milatović, J., \& Krešić, A. (2016). How the Western Balkans can catch up. EBRD Working Paper 185. doi: 10.2139/ssrn.3119685

Shimbov, B., Alguacil, M., \& Suárez, C. (2016). International production networks and economic growth: The case of the Western Balkan countries. Eastern European Economics, 54(1), 49-70. doi: 10.1080/00128775.2015.1112749

Special Economic Zones - not so special. (2015, April 4). The Economist. Retrieved from: https://www.economist.com/leaders/2015/04/04/not-so-special

Stanionyte, L., \& Gnamus, A. (2016). Report - the role of smart specialisation in the EU enlargement and neighbourhood policies. Retrieved from: https:// danube-inco.net/object/document/18737/attach/0_D5_29_S3_role_in_the_ EU_EN_policies-FINAL.pdf

State Statistical Office. (2016). Statistical Yearbook of the Republic of North Macedonia 2016. Skopje: State Statistical Office.

Wang, J. (2013). The economic impact of Special Economic Zones: Evidence from Chinese municipalities. Journal of Development Economics, 101, 133-147. doi: 10.1016/j.jdeveco.2012.10.009

Western Balkans Summit. (2015, August 27). Final declaration of the chair of the Vienna Western Balkans Summit. Retrieved from: https:/ec.europa.eu/ neighbourhood-enlargement/sites/near/files/pdf/policy-highlights/regionalcooperation/20150828_chairmans_conclusions_western_balkans_summit.pdf

Wyrwa, J. (2014). Smart specialisation - a novel approach towards region development in Poland. Acta Scientiarum Polonorum Oeconomia 13(3), 143-154. 